\title{
THE BATTLE OF MANZIKERT: GENESIS OF INTERNATIONAL GULTURAL CULTIVATION
}

\section{Alonzo T. STEPHENS}

(Tennessee)

Turkey is a miniature continent, a land, bounded by seas, within which are mountains with coastal accessibility, a land that lies in Asia and Europe. Turkey has a geographic position between two continents and near a third. It is a land that knows peace and war yet it is a place where diplomacy has flourished.

The Battle of Manzikert in 1071 ranks as a decisive historical event. International scholars are interested in this battle of some 900 years ago, but when one steps backward in time one realizes that the events and challenges of the present were in many instances shaped by the happenings, mistakes and successes of the events of 1071.

The Middle Ages knew nothing of all those ideas which have rendered the present sentiment of justice, timid and hesitating. Instead of lenient penalties inflicted with hesitation, the Middle Ages knew but the two extremesthe fullness of cruel punishment and mercy. When the condemned criminal was pardoned, the question whether he deserved it for any special reason was hardly asked, for mercy had to be gratuitous, like the mercy of God.

The Battle of Manzikert was a military show but it also had other aspectscultural, intellectual, economical, nationalistic, racial, and scientific and technological. Whereas the Battle of Yarmuk assured the triumph of Islam in the southwest, the Turkish victory at Manzikert foreshadowed dominance of the Moslem religion and culture in eastern Asia Minor. ${ }^{1}$

The offensive power of the Arabs was greatly lessened in the eighth century by internal struggles. The Ommidd Caliphs of Damascus were overthrown in 750 and a capital was set up at Baghdad in 762. Although this new Abbasid Caliphate endured until it was destroyed in 1258 by the Tatars, its rulers were unable to completely control the sprawling Moslem Empire,

1 William Yale, The Near East: A Modern History, (Ann Arbor: University of Michigan Press, 1958), p. 10. 
There was progress in spite of the constant challenges. After the era of great prosperity and political power of the rule of Harun Al Rashid, the Abbasid Caliphate grew so weak that in order to maintain its control over the Arab bands of Western, Asia it was obliged to employ mercenary troops recruited from a nomadic Turanian tribe known as the Seljuk Turks.

In the tenth century the Abbasid rulers came to be little more than puppets of the Seljuk Turks. By the eleventh century Turkish tribes were moving into the eastern part of Asia Minor in increasingly large numbers.

The Byzantine army sent against them was defeated at the Battle of Manzikert in 1071 and the chain of events which followed makes it loom as one of the most decisive contests in the long history of the Near East to the British defeat of the Ottoman armies in Palestine and Syria in 1918.9

Turkey in Europe with Istanbul (formerly Constantinople) and Adrianople, is a rolling agricultural land. Asiatic Turkey has a fertile coastal strip; its center is occupied by the vast, semi-arid Anatolian plateau $(1,500-1,900$ feet high), which is surrounded by a fringe of hills and mountains. Highest are the Taurus range and its slopes and spurs, in the South of the Anatolian peninsula, and the Transcaucasian ranges in the northeast culminating in Mt. Ararat on the Soviet border.

The original Turks most probably lived in the region north and wast of China, in South Siberia and in Turkestan. Here the oldest Turk inscription, Orkhon Inscription have been found.

The Seljuks appeared in Iran in the 10th century, embraced Islam, and made themselves masters in the 11th century of Khorezm and Iran, and entered Baghdad in 1055; under the leader Alp Arslan, they conquered Georgia. Armenia and much of Asia Minor, overran Syria and defeated (1071) the Byzantine emperor Romanus at Manzikert.

Their irruption was a major factor in bringing about the crusades, during which a three cornered struggle among Seljuks, Christians, and Egyptian Mamelukes developed. Alp Arslan's son, Malik Shah, ably administered his huge empire. He was the Protector of Omar Khayyam who reformed the calender.

Turkey was administered from chief cities the center of the province. The Turks-Turkic speaking peoples thus through war, commerce, and commu-

2 See J. Huizinga, The Waning of the Middle Ages, (London: Edward Arnold and Company, 1924). 
nication by the 11th century became a mixture of Uighurs of West China, the Uzbeks of Central Asia, and the Ozmanlis of Turkey. Thus it was impossible to speak of them as ethnic or a pure racial family. The cultural family was kept intact by administrative tact, military genius and the unifying forces and precepts of Islam. There was also a unifying force of related languages. Even today many Hungarian words are of Turkish origin.8

Romanus IV, (Romanus Diogenes), Byzantine emperor (1071-72) succeeded Constantine $\mathrm{X}$ by marrying his widow, Eudocia Macrem Bolitessa. After Romanus IV was defeated by Alp Arslan at Manzikert in 1071 he was ransomed and promised to pay tribute but he was deposed by his step son, Michael VII, and died shortly afterwards. Thus ended the long reign of that family. Romanus III the Byzantine emperor (1028-38) had married Zoe, daughter of Constantine VIII and took her to the throne. He depleated the treasury by his generosity to the victims of a plague and earthquake and by his building mania. His defeats by the Saracens near Antioch in 1030 helped to weaken the family treasury.

A strong warring people sought peace but had to constantly defend their land from inside and also outside forces. The climate of Turkey is generally temperate thus leading itself to agricultural and pastoral pursuits. They early became experts in cattle, sheep, goats, horses, and water buffalo. The arable land yielded wheat, barley, oats, rye, maize, tobacco, cotton, flax, hemp, and opium poppies. Grapes, olives, raisins, figs, apples, hazel nuts and walnuts helped to make the people strong and confident. Moreover, these resources made them great fighters simply because they had something to defend and in the case of attack gave the resources for sustained retaliation.

In modern times one is reminded that Turkey produces tobacco, carpets, mohair products, pottery, and brass and copper. Turkey is also one of the world's exporters of chrome and of merschaum. Turkey is a great nation of historically proud peoples.

That which sounds like the major mode of Western Europe was specifically a Persian element. Melody types which corresponded to the Hindu ragas was the system of Magams. There was a borrowing of Arabian music principle

3 William Yale, The Near East: A Modern Histry, (Ann Arbor: University of Michigan Press, 1958), p. $10 \mathrm{ff}$. 
form-Nuba, a sort of Cantata in nine parts, some of which was instrumental, some vocal, using the long and short lute. 8

When not at war the Turks were a happy people. Their music included some elements of Greek and Hindu music and elements of Semitic musical cultures-Assejrian and Hebrew that came in with greater acceptance in the tenth century.

Al Faraki (10th century) was the principal theorist that introduced the Greek conception of Tetrachonds into the tonal system. After his reform the Arabian gamut was extended to include 10 notes roughly corresponding to the chromatic scale of western music.

One can also see the merger of church construction in Turkey. The churches were decorated with mosaics and paintings. Mosaics demanded time and patience and skill from the artist and they endured longer. The church decorations represented the stories from the old and new testaments, martyrdoms, portraits of high churchmen and the palace, landscapes, sea scapes, hunting scenes and victories symbolized by emperors.8

Strategic Setting:

The main battle of Manzikert in 1071 took place near the small town of Malazqit, an important village 85 miles southwest of Erzurum. This was an important town of ancient Armenia. The Battle secured most of Asia Minor to the Seljuks.

Asia Minor, the peninsula in extreme West Asia is often called Anatolia. The Black Sea on the North, the Mediterranean on the South and the Aegean arm of the Sea of Marmara and the two straights-the Bosphorus and Dardanelles made one of the most famous water-ways of the world.

Asia Minor was the chief meeting place of Oriental and Occidental civilization in ancient times for it linked Mesopotamia with the Tigris and Euphrates rivers to the Greek countries on the Mediterranean.

4 See H. G. Farmer, A History of Arabian Music, 1929 and Curt Sachs, The Rise of Music in the Ancient World, 1943.

5 Charles George Crump and E. F. Jacobs, The Legacy of The Middle Ages, (Oxford: Clasenden Press, 1926), p. 132.

C. F. Beckingham, Atlas of the Arab World and the Middle East, (London: Macmillen \& Co., LTD, 1960), pp. 38-40. 
The Turks, the defenders had the favorable strategic inland position. There were important rivers such as the Yesilurmak, the Hursit, the Coruh that ran north into the Black Sea. There was also the Euphrates flowing from the Munzar mountains where several branches made it an important water-transportation route.

Not to be omitted was the Tigris (Dicle) and the east branch gaining water from the sweet water lake Van and runs from Hakari mountains. Thus the Turks could defend with strength and military authority. The mean annual precipitation around Erzurum for at least 100 miles was between 300 to $1,000 \mathrm{~mm}$ or 12 to 40 inches north a few miles away from the Black Sea coast at Trabzon was over $2,000 \mathrm{~mm}$ or over 80 inches.

Turkey's minerals-coal, lignite, oil, iron, chrome, lead, copper, sulphur-are in modern times useful for the following industries: iron and steel, cotton, wool, silk, carpets, sugar, coal oil, tobacco, paper, and oil refineries.

Center of Economic Activity:

Manzikert may be introduced in another manner-the center of economic activity.

As Constantinople grew in size it depended more and more on the work of the farmers. The serfs lead wretched lives while the landlords lived in splendor. Craftsmen organized in guilds under rigid state supervision left the smaller villages. After the Moslem conquest, silkworms were cultivated. Also many woolen merchants in cities like Antioch and Alexandria moved to Constantinople and rising above religious bigotry, developed profitable businesses.

Constantinople, now a great commercial center attracted merchants and traders from India, Ceylon, China, Syria, Egypt, Spain, the Balkans, Italy, France, Russia, Scandinavia and Britain. Byzantine gold (bezants) was' accepted as a medium of exchange the world over.

Thus the Byzantine empire and eventually Constantinople would fall to the most formidable of the Asitaic invaders, the Turks, who, originating in Turkestan, made their way south and east and in the ninth century accepting Islam. 
Byzantine Rise and Fall.

The Manzikert battle in 1071 was no accident. There was a cause and result. One must look at the developments in the Byzantine Empire for some explanation of the cause and result.

Within the Byzantine empire the authorities by $700 \mathrm{~A}$. D. held a firm grip only on Thrace and Asia Minor (including Armenia. There was a loose hold on the Balkans, parts of Italy, Ravenna, Venice, and Rome. Sicily and Sardinia-Carseia also were fragments held by the successors of the once great Roman world empire.

Heraclius' domestic reforms helped to check the Moslem advance. In 717 the Greeks were able to check the almost annual Arab army raids on Constantinople. Thus Constantinople from about 840 to 1050 A. D. rivaled Baghdad as a great city of the ancient world. Trade, economy, culture intellectual pursuits and the military flourished.

The civilization of the Byzantine dynasties 867-1057 was new and different from that of Rome and Greece. They tried to cultivate their inheritancetheir social and political institutions - characterized in the institutional development of the autocracy, the army, and the church.

The Byzantine emperors called themselves "autocrats." They were rulers dependent upon and accountable to no one but themselves and believed that all earthly power derived ultimately from them. In theory the emperor was elected by the higher officials (the Senate) with subsequent ratification by the army and the people. In practice many ambitious men would seize and keep power in his family by having his son elected and consecrated during his own lifetime. The emperor lived in the beautiful and splendid palace. The Persian King Court ceremonial dazzled visitors and set the stage for the conduct of public and private endeavor.

Many emperors as capable men, led armies and took personal charge of the administration. The detailed work, inherited from late Roman times, was done by the enormous bureaucracy which was arranged in an elaborate hierarchy. Each level of the hierarchy had its own titles, honors, and privileges. Punishment was harsh, secret police were numerous and ruthless.

The armed forces of Byzantine adopted the use of cavalry, which they copied from the Persians. They had and used most efficienly light cavalry, for scouting and quick raids, heavy cavalry (cataphsacts), horse and rider protected by coats of mail carrying long lances. There was also the infantry 
with bows and arrows, spears, and military engineers who built bridges and made fire on enemy boats and land installations. After Justinean's reign the army was conscripted.

From the "themes" military districts, the Byzantine army reached the level of 125,000 men. In time military commanders superseded civilian governors in the themes. Protected on the north by the Black Sea, the Adriatic Sea, the Aegean Sea and the Mediterranean Sea, the Byzantine military machine neglected its navy whose chief job was to drive back Moslem pirates.

The Byzantine or Eastern church, and the Orthodox church by the tenth century sought to follow the ideals of Constantine and Justinian. They sought to develop and preserve theological uniformity. Orthodoxy taught the doctrine of the Trinity - the equality of the three "Persons." Yet the system opened the way to heresy and the development of different tenets and eventually different sects.

During the Isaurian dynasty (717-920) a group, the "Iconoclasts" went about smashing idols made into images. But soon another group, the "Iconodules" (image-worshipers) were victorious. With the victory of the Iconodules the Iconoclasts accepted what they considered the purer worship of Islam, a decided setback to the powerful orientalizing forces in the Byzantine Empire.

The battle between the Eastern and Western churches remained bitter throughout the eighth, ninth and tenth centuries.

The Popes insisted that they held supreme authority over the entire Christian church. The patriarchs insisted upon complete equality. Finally in 1054 the Roman church denounced the Eastern church as schismatic while the Orthodox church denounced the Roman church as heretical. The only theological difference separating the Eastern and Western churches was the Procession of the Holy Ghost (Filioque). The Greeks denounced the words and the Son (in Latin, Filioque) as an unauthorized insertion by Rome. Eastern churches conducted their services in National languages and allowed priests to marry. However, certain groups of Eastern Christians (Uniates), accepted papal supremacy and were, therefore, recognized by the Pope.

The Greeks never made great inroads into the peninsula area of Islam that was protected by the Black Sea, North, Eastern, Mediterranean and the Aegean but they did convert Slavic tribes in Bohemia, Moravia and Russai. 
The most important victory of Orthodox missions came about around 990, when Prince Vladimir, the ruler of Kiev in southeastern Russia accepted the Greek form of Christianity. Thus the baptized was the seed of the Russian Orthodox church, and eventually the largest and most powerful branch of the Eastern church.

From the above description one can see that the Middle East, especially the area near and surrounding Constantinople, was an area of constant and almost violent religious conflict. This conflict had its effects on other aspects of life-economic, political, educational social, industrial and of course militaristic.

\section{MANZIKERT: A TURKISH REVIVAL}

The Battle of Manzikert in 1071, when Emperor Romanus IV Diogenes was defeated by Alp-Arslan, was a complete victory for the Turks. A brief review of the Ottoman Empire just prior to the event of 1071 revealed interesting strengths.

The preceding pages suggests that a vacuum existed and for some time the Turks were conditioned to exploit the opportunity. Emperors of the Ducas dynasty taxed the Anatolian provinces and withdrew financial support and governmental privileges from frontier districts. After the defeat at Manzikert, this group deserted the empire.

Industry and commerce gave the already sufficient agricultural base wealth and luxury. Manufactured goods were produced in the great cities. Luxury goods were produced and hundreds of churches and monastries flourished. Pageantry in the imperial court and sumptuous living was much enjoyed and the wealth of silk, gold, jewelry, reliquaries, enameled wares, fine glassware and all the precious and refine luxury of the medieval age dazzled western visitors. ${ }^{6}$

Constantinople was filled with warehouses, depots, banks, and money changers that promoted foreign and domestic commerce. Surplus produce placed on ships was navigated between Constantinople and Cherson, Trebizond, Salonica, Venice, Amalfi and Genoa. A standard tax of ten percent on

6 Sidney N. Fisher, The Middle East, A History, (New York: Alfred E. Knopf, 1966), p. 154. 
exports and imports brought additional revenue. Yet commerce in soap, gold, raw silk, court ceremonial robes, unsewn fabrics and salt fish could not be exported. Industry and commerce were strictly regulated by the government. ${ }^{7}$

Individual guilds-industrial, commercial, and financial and highly organized-were fully developed before the year 1071 . The guilds were restrictive, repressive and conservative. ${ }^{8}$ Yet they were functional and helped to keep quality high and goods desirable. After 1071 an area of prosperty was somewhat disorganized when Asia Minor was overran with Turkish bands. In the depleated state a desperate call resulted in the formation of the Crusades.

The Crusades, often praised in the West, did more harm than good. Italian merchants traveled in the Crusader's wake founded Latin states and carried on trade through Syria. The fall of Constantinople to Venetian merchants and soldiers in 1204 terminated abruptly the Greek Empire. Its society and civilization collapsed. The Orthodox church was latinized; monastaries disappeared; wealth of the churches was carried off; the University closed and literature, books and learning lost value and support.

The immediate twenty years preceeding the Battle of Manzikert were even more dramatic. The true founder of the Samanids dynasty, Seljuk's grandson, Tughril, ascended to power in Khurasan. Defeating the Chaznawids and ejecting the Buwayhids from Iran, Tughril entered Baghdad with an army in 1055. He was king of the East and the West and Al-Sultan. Henceforth, Seljuk rulers adopted sultan as their official title.

Tughril's nephew, Alparslan followed as sultan and succeeded in controlling lands of the Muslim world from the frontiers of China to the Mediterranean. Thus it was Alparslan who opened Asia Minor to his Turkish nomads. His horsemen camped on the shores of the Sea of Marmara. His son, Malikshah pushed westward and southward, taking Damascus and Jerusalem and threatening Fatimid Egypt. Baghdad now as the capital, became the hub of the eastern Muslim universe and recaptured much of its abandoned glory. ${ }^{9}$

Nizam Al-Mulk, the principal Vizir of Alparslan and Malikshah, was a cultured and versatile Iranian. He founded the renounced Nizamiyah Academy or University in Baghdad and wrote the Siyasatnamah, a scholarly

\footnotetext{
7 Ibid., p. 154.

8 Ibid., p. 155.

9 Fisher, op. cit., p. 94.
} 
monograph on the science of politics and government. He revised the calendar and became a patron of the Persian astronomer-poet Umar-Khayyam. ${ }^{10}$

Under the rule of Malikshah a merchant could travel alone unmolested from Samarkand to Aleppo. But in 1092 Malikshah met his death and Nizam Al-Mulk was assassinated. The civil war between members of the family was stepped up and soon there was a development of petty Seljuk states. Baghdad, Damascus were ruled by sons. Konya was ruled by a cousin. Jerusalem, Edessa, Mosal, Diyarbakir and Amasya were ruled by other cousins. The year 1194 was the year of the demise of the empire that was saved in the great and significant Battle of Manzikert.

The Battle of Manzikert resulted in a brief revival. Arabs and Jews from the Near East and Asia passed astronomy, medicine, mathematics and sciences to the West. The Arabs with their conquest extended throughout the southern coast of the Mediterranean and the greater part of modern Spain. The soldiers on the battle fields of 1071 retreated and returned to their home camp with a new culture-a learning expanded beyond the projections of their most learned philosophers. New raw materials and finished products were exchanged and new words crept into each of the peoples' language. Divinity, law and medicine were radically changed.

Finally the political advance was perhaps the greatest. Political control led to the pacification of towns, secured the workers while they dug deeper and into new mines where they found brass, iron, turquioses, santalem, gold beryl and malachite.

The Seljuk ruler, Tughril Beg made Vishapur his capital in 1038 as did his nephew and successor, Alp Arslan (1063-1072), whose name is still kept in the mound called Tapah-i Alp Arslan, near the ruined sity that lies east or southeast of the present city. It was under Alp Arslan's son, the renowned Malik Shah (1073-1092), that the three celebrated school fellows of Nishapur, the poet, Omar Khayyam, the statesman, Nizam Al-Mulk, and the founder of the Assassins, Hasan-i Sabbah, are said to have taken an oath in blood that whichever of the three should first achieve success in the world would help the other two to gain higher preferment-an obligation that is said to have been dutifully fulfilled. ${ }^{11}$

10 Ibid., pp. 94-95.

11 Abraham Valetine Williams Jackson, From Constantinople to the Home of Omar Khayyam (New York: The Macmillan Co., 1911), p. 254. 
Thus the Battle of Manzikert gave freedom, security and time for the Turkish peoples to develop a new consciousness and nationhood that would make Turkey a great cultural melting pot. The Battle safeguarded Asia Minor from an invasion of Christian dogma thus allowing the area to nurture her own religious, cultural and intellectual germs. Eventually, Constantinople would be Turkish and thus the Black Sea area would be controlled and Turkey would be a pacified nation for several hundreds of years. Thus historians with hindsight could look to 1071 as a great year, a significant year, and a turning point.

\section{SELECTED BIBLIOGRAPHY}

Adivar, Halide Edib, Turkey Faces West: A Turkish View, New Haven: Yale University Press, 1930.

Allen, Henry Eleska, The Turkish Transformation: A Study of Social and Religious Development, Chicago: The University of Chicago Press, 1935.

Anderson, Anthony Dolphin, The Structure of the Ottoman Dynasty, Oxford: Clarendon Press, 1956.

Baker, James Lt. Col., Turkey, New York: H. Holt and Company, 1877

Baska, Kov, Nikulai, Aleksandrovich, The Turkic Language of Central Asia, London: Central Asian Research, 1952.

Cahen, Claude, Pre-Ottoman Turkey: A General History 1071-1300, New York: Taplinger Publishing Company, 1968.

Clark, Edson Lyman, The Arabs and the Turks: Their Origin and History, Boston: Congregational Publishing Society, 1876.

Coles, Paul, The Ottoman Imprint on Europe, New York: Harcourt Brace and World, 1968.

Davis, William Stearns, $A$ Short History of the Near East From the Founding of Constantinople 330. A. D. to 1922, New York: The Macmillan Company, 1922.

Ekrem, Selma, Turkey, Old and New, New York: Charles Scribner's Sons, 1947.

Eton, William, A Survey of the Turkish Empire, London: T. Cadell, 1799. 
Gibbon, Herbert Adams, The Foundation of the Oitoman Empire, A History of the Osmanlis Up to the Death of Bayezid I, 1300-1403, Oxford: Clarendon Press, 1916.

Horton, George, The Blight of Asia: An Account of the Systematic Extermination of Christian Populations by Mohemmedans, Indianapolis: The Babbs-Merrill Company, 1944.

Jackh, Ernst, The Rising Crescent: Turkey Yesterday, New York: Farrar and Rinehart, 1944.

Knalles, Richard, The General History of the Turks Lives and Conquests of the Ottoman Kings, London: A Jslip, 1603 (Film 1550-1610).

Lados, Stephen Pericles, The Exchange of Minorities, Bulgaria, Greece, Turkey, New York: The Macmillan Company, 1932.

Lengyel, Eniel, Turkey, New York: London, 1941.

Mardin, Şerif, The Genesis of Young Ottoman Thought, Princeton, New Jersey: Princeton University Press, 1902.

Newman, Bernard, Turkish Crusades, London: Hale, 1951.

Penzer, Norman, Mosley, The Harem: An Account of the Institution As It Existed in the Palace of the Turkish Sultans, London: G. G. Harnap and Company, 1936.

Saab, Hassan, The Arab Federalists of the Ottoman Empire, Amsterdam: Djambatan, 1958.

Shotwell, James T. Thoman, Turkey At The Straits: A Short History, New York: The Macmillan Company, 1920.

Spencer, Captain Edmund, Turkey, Russia, the Black Sea, London: G. Routledge and Company, 1885.

Tobin, Chester M., Turkey: Key to the East, New York: G. P. Putnam and Sons, 1944.

Toynbee, Arnold Joseph, Turkey, New York: Scribner's Sons, 1927.

Urguhart, David, The Spirit of the East, London: H. Colburn, 1838.

Williams, Gwyn, Tiskey: A Travelers' Guide and History, London: Tahes, 1967. 